\title{
Peer Feedback Strategy Towards Sixth Semester Students' Ability In Translation
}

\author{
K. Dedy Sandiarsa $S^{1}$, Muhamad Suhaili ${ }^{2}$ \\ ${ }^{1,2}$ Universitas Pendidikan Mandalika
}

\begin{tabular}{l}
\hline \multicolumn{1}{c}{ Article Info } \\
\hline Article history: \\
Received 30 Desember 2021 \\
Publish 04 Januari 2022
\end{tabular}

Keywords:

Peer Feedback Strategy

Translation

\begin{abstract}
This Research aimed at finding the effect of Peer Feedback strategy towards fifth semester students' ability in translation subject at S1 Degree of English Department FBMB, Mandalika University. This research was quasi experimental design of experimental research. The population was 3 classes (118 students), in which 2 classes were selected as the sample that was divided into two groups; Class A with 30 students as the experimental group and Class B with 30 students as the control, the groups were divided by using Simple Random Sampling technique. The data collection got from translation test of translating texts given, then the data were analyzed by using SPSS 2019 computer program for windows 10. The result showed that the significant value of $=0.000$ was lower than 0.05. Therefore, it can be concluded that the students in Class A who were taught by using Peer Feedback strategy have higher score in translation than the students of Class B who were taught by using the grammar translation strategy. Based on the conclusion, the researcher suggested that Peer Feedback strategy should be used to teach translation for the fifth semester students at S1 degree of English Department of FBMB, Mandalika University.
\end{abstract}

This is an open access article under the Lisensi Creative Commons Atribusi-BerbagiSerupa 4.0 Internasional

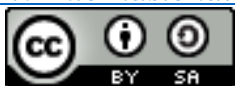

Corresponding Author:

K. Dedy Sandiarsa $S$

Universitas Pendidikan Mandalika

\section{INTRODUCTION}

Translation is one of the basic subject in S1 degree of English department, almost all of the University that learn English as a foreign language suggest Translation as the importan subject that should be learnt by their students. Beside four language skills (listening, speaking, reading and writing) and language elements (phonology, structure and lexical) there are some spesific skills that have to be learnt and trained by the students in English Department program, such as Translation, Interpreting, English for Business, ect. Every University hopes that their students may have spesific skills related with English to make their students ready to take the oppurtunities after graduation. As stated by Hatim and Munday (2004: 3), translation is a phenomenon that has a big effect and impact on everyday life. The statement of Hatim and Munday should be a consideration for the Head of English Departments to program Translation as the main subject in their University.

In learning Translation, there are some aspects that have to be focused on, such as the rich of vocabulary, comprehend the meaning of English phrases, and understand the culture of source and target languages. Moreover the skill of translation is supported by the skill of writing and reading of both languages, as the result of research found by Agustini (2018) at SMKN 2 Kota Jambi, there was a significant correlation between writing skill and translation, the writing skill highly contributed the translation skill.

The translation learning theories explained previously have to be considered in teaching translation, however that was not appropriate with the students' ability in fifth semester, most of the students felt hard to translate a text given. Based on the discussion the researcher conducted 
in the classroom, they stated that there were many English phrases that hard to be translated because the limit of dictionary that distributed the meaning of English phrases. They still focused on word by word translation technique, this technique is hard to be aplied in EnglishBahasa Indonesia translation, because both languages have different cultures.

Teaching English as a foreign language is the challenge for the researcher, the researcher has to ensure his students' understanding about the culture of target language, in this case is English, the skill of students in comprehending the English text and the skill of students in describing the information got into a good written text. Based on theoritical found by the researcher, he would like to apply the Peer Feedback strategy to cover the students' need, the writing skill of the students became the most important thing that should be focused on to solved the translation problem. Moreover the good interaction between lecturer and the students be the spesific part of translation learning process, by effective interaction, the students have no anxiety, may have a good self-confidence or may have high motivation that can help theirselves in training their translation skill.

According to Yang et al., (2006) Peer Feedback strategy can help to students to have a good critical thinking, and can improve the social interaction among students. These advantage of Peer Feedback strategy was appropriate with the students' need in fifth semester students at English Department of FBMB, Mandalika University. Sujannah (2017) also states that Peer Feedback can realease the students' anxiety and enhance their confidence. She also concluded in her research, Peer Feedback can be used as an effective strategy in teaching translation.

Finally, based on the theoritical and empirical review described previously, the researcher would like to apply Peer Feedback as a strategy in teaching translation to cover the students' need and hopely can bring the benefit for the students toward their translation skill.

According to Warwal (2014), Translation is the process of transfering meaning of a text and the subsequent production of that equivalent text. In this case, the researcher would like to clarify that in English Department of FBMB, Mandalika University has two different subjects that have same focuses, Translation and Interpreting. Both subjects aim to make the students become bilingualism, however in translation, the students practice with document in which the students practice on transfering the meaning from the reading text of source language form and practice to describe those reading text meaning into target language form writtenly and in interpreting the students practice to comprehend their listening skill in source language and practice to transffering the meaning from what they have listened to target language spokenly.

There are some experts explained that there are some method that can be used to make the trranslator easier to translate the document. As stated by Newmark (1988:45), there are some methods of transfering the meaning of the text to another language; 1) word-for-word translation. This method can be used when the source langugae and target language are interlinier; 2) literal translation. This method can be used to translate legal document, technical or scientific text; 3) faithful translation. By this method, the translator transfering the contextual meaning of source language to target language and put that meaning based on the grammatical form of target langugae; 4) semantic translation. This method is a natural translation, the cultural words of source language are translated into its equivalent in target langugae; 5) adaption translation. This method commonly used to translate poetries, script, then the process of translating, the translator transfering the text without changing the themes, characters, or plot of the text of source langugae; 6 ) free translation. This method consider the whole meaning of the text, then it may involve additions or deletions to keep the flow and the natural of the meaning text of the target language; 7) idiomatic translation. This method let the translator to use familiar expression, idioms colloqualisms in target langugae which may not exist in the text of source language.

The students who learns translation, should understand every method as explained by Newmark. Then the researcher would like to apply Peer Feedback technique to help the students easier to understand the material and may have good critical thinking in translating the text. 
The researcher's statement also appropriated with Peterson (2010:2), He said that peer feedback has the positive impact; the writer in this case can be said the translator can use their critical thinking to write an understanable sentences in the target langugae and; The students and their peers able to ask for clarification about something that is confusing in describing the meaning of the target language.

\section{RESEARCH METHOD}

Based on the research problem discussed in this article, the researcher would apllied quantitave approach as the research method. The Population consisted of 3 classes with 118 students. In this study the researcher used two samples from which generalization made for the population. The sample of the study used Simple Random Sampling strategy. In this case, the researcher provided 2 classes in which each class consisted of 30 students. The researcher applied translation test and for the scoring term, the researcher was subjective and based on the translation indicators.

In analyzing the data that have been collected, the researcher used SPSS 2019 computer program for Windows.

\section{RESEARCH FINDING}

There were two variables in this study: Peer Feedback strategy and Translation. Peer Feedback strategy was independent variables and then translation was dependent variable. The collected data were obtained by giving test to know students' ability in translation. The data were analyzed to measure the range of the data, the mean, median, mode, and standard deviation. The collected data were taken from the result of research instrument used in posttest of the samples in this study. The data were calculated by using SPSS 19. Software for windows.

The data of translation score were collected through research instrument given. The maximum score was 100 and the minimum score was 0 . The empiric score showed that the highest score: 92, the lowest score: 76 . Moreover, mean score: 82.40, median: 82.00, mode: 80, standard of deviation: 4.407.

The mean score and the standard deviation of the data were indicated that the students' score of translation was in good category. The mean score and standard deviation indicated that students score of control group was relative in not good category. The research analysis of translation as independent variable in this research was measured by using two tailed descriptive analysis test and T-test. Finally the result showed which groups have positive impact toward the students' translation ability according to the teaching strategy used in this study. The researcher measured the significant value of t-test with two tail computation, therefore it showed that the value of Sig $>0.05$ (higher), it meant that the null hypothesis which stated "there is no effect of Peer Feedback strategy towards students' ability in translation" was rejected and Ha which stated "there is any effect of Peer Feedback strategy towards students' ability in translation" was accepted. It can be concluded that the independent variable (Peer Feedback technique) has a significance effect towards dependent variable (translation)

Based on the translation score of the students who were taught by using Peer Feedback was higher than the score of the students who were taught by Mind Mapping. By the application of the teaching steps of Peer Feedback technique, the students become more active to participate the teaching learning process, Peer Feedback help the students to receive more individual comments as well as giving reviewers to the others, this interaction could help the students to develop their critical thinking in translation.

Finally, based on the result of the computation of the data, the null hypothesis in this study can be stated as rejected and alternative hypothesis can be stated as accepted.

\section{CONCLUSION AND SUGGESTION}

Peer Feedback strategy has a significant effect towards students' ability in translation. It can be seen from the score of the value of Sig > 0.05 (higher), which means that the null 
hypothesis which stated "there is no effect of Peer Feedback strategy towards students' ability in translation" was rejected and Ha which stated "there is any effect of Peer Feedback strategy towards students' ability in translation" was accepted. Peer feedback is appropriate in teaching translation. Peer feedback helps the students to understand the learning material and be able to develop students' performance in transfering the meaning of text.

Based on the conclusion previously, The lecturer should make the students to be more active in English learning, especially in translation subject, the lecturer should selective to choose appropriate teaching technique, One of the effective strategy to improve students' translation is Peer Feedback strategy.

\section{REFERENCE}

Agustini (2018). The Correlation between Students' Translaion Ability and Their Writing Ability at the Tenth Grade Students of SMK Negeri 2 Jambi in the Academic Year 2018/2018. Jambi: Universitas Silam Negeri

Hatim \& Munday (2004). Translation, an Advanced Resource Book. Canada: Routledge.

Newmark, P. 1988. A Textbook of Translation. London: Prentice Hall.

Sujannah, Wahyu Dini. (2017). Online Peer Feedback as a Strategy to Improve Students' Translation Skills. Jurnal Pendidikan Humaniora, 5(4), 165-168. https://pdfs.semanticscholar.org/9cab/ead5eb013d384dd011f4945da5b43d80c3a4.pdf.

Downloaded on December 12, 2021.

Warwal, Surjeet Singh. (2014). Translation Process and Problem of Translation in World Classics. Indian

Scholar. https://www.researchgate.net/publication/316655699_TRANSLATION_PROCESS_AN D_PROBLEM_OF_TRANSLATION_IN_WORLD_CLASSICS. Downloaded on December 17, 2021

Yang,M., Badger, R., \& Yu, Z. (2006). A comparative study of peer and teacher feedback in Chinese EFL writing class. Journal of Second Language Learning, 15 (3), 179-200. https://www.researchgate.net/publication/223579470_A_comparative_study_of_peer_an d_teacher_feedback_in_Chinese_EFL_writing_class . Downloaded on December 12, 2021. 